\title{
Література:
}

1. Анатолій Калитко. Живопис. Альбом / Автор-упорядник Молинь В. Львів, 2020. 80 с., іл.

2. Димшиць Е. О. Твори декоративно-прикладного мистецтва в натюрмортах українських художників (кін. 1950-х - поч. 1970-х років). Народна творчість та етнографія. 1986. № 3, С. 59-61.

3. Зорко А. Є. Натюрморт у класичному живописі та академічній художній освіті. Вісник КНУКіМ. Серія : Мистецтвознавство. 2011. Вип. 25, С. 36-43.

4. Молинь В., П'ясецька В. Мелодія живопису Анатолія Калитка. Альбом. Івано-Франківськ: Місто НВ, 2012. 128 с., іл.

5. Петрова О. Етніка у творчості вчених художників. Актуальні проблеми мистецької практики і мистецтвознавчої науки. 2016-2017. Вип. 8-9, С. 50-58.

DOI https://doi.org/10.30525/978-9934-26-004-9-54

\section{ТВІР І. ДРЯПАЧЕНКА «КУТОЧОК САДКА РОСІЙСЬКОГО КОНСУЛА У ФЛОРЕНЦЇ̈»}

\author{
Мячкова Т. O. \\ аспірантка кафедри теорії та історії мистецтва \\ Національної академії образотворчого мистеитвва і архітектури \\ м. Київ, Украӥна
}

На сайті Російської антикварної галереї було розміщено зображення картини І. Дряпаченка «Куточок саду». В інформації до твору вказано: картон, олія, 42,7х70,5 см, перша третина XX ст. [2]. У творі відображено характерне для теплого клімату Італії прикрашення саду. Зокрема, по центру композиції, поміж грунтової доріжки та огорожі, стоять діжки із лимонними деревами та квіти у горщиках. Оригінальний ракурс, камерність мотиву, фрагментарність зображення створюють відчуття присутності у затишному куточку саду садиби. Можна припустити, що дана картина «Куточок саду» - це твір І. Дряпаченка 1912 р. «Куточок садка Російського консула у Флоренції».

Про перебування І. Дряпаченка у Флоренції наявна інформація в документах Центрального державного архіву-музею літератури i мистецтва України. Відомо, що 1912 р. Рада Вищого художнього 
училища при Академії мистецтв у Петербурзі відрядила І. Дряпаченка і О. Каднікова до Італії [3; С. 149]. Результатом поїздки стало створення I. Дряпаченком низки живописних робіт, а саме: «Святе сімейство», «Голова італійки», «Бабуся-італійка», «Куточок садка Російського консула у Флоренції». Їхні зображення, опис, розміри та місце знаходження невідомі [3; арк. 95]. Того ж року художником створена картина 3 видом на Пьяццале Микеланджело у Флоренції, що знаходиться у приватній збірці (Україна) [1; С. 32].

3 другої пенсіонерської поїздки 1913 р. І. Дряпаченко привіз такі твори, як «Світлячки» (НМЛ), «Поминальний день у Флоренції» (НДМ РАМ, СПб), «Вулиця ввечері» (ДРМ, СПб) та «Голівка циганки. Гренада» (місце знаходження невідоме) [4; арк. 95-98]. Серед робіт створених художником за кордоном $є$ тільки одна, що збігається за назвою 3 «Куточок саду...» та містить в назві вказівку на італійську місцевість. Отже, наведені вище факти дають підстави стверджувати, що твір І. Дряпаченка 3 видозміненою назвою «Куточок саду» 3 сайту Російської антикварної галереї є твором І. Дряпаченка 1912 р. «Куточок садка Російського консула у Флоренції». Картина експонувалася 1913 р. на Весняній виставці в залах Академії мистецтв в Петербурзі [4; арк. 95]. Це - єдина наявна інформація про це полотно художника. Зображення, опис, розміри ії невідомі.

3 огляду на те, що місце знаходження переважної більшості творів видатного українського живописця і графіка І. Дряпаченка (1881-1936) нині невідоме, поява через сто років його твору є дуже важливим для подальшого дослідження та збереження творчої спадщини митця.

\section{Література:}

1. Каталог Аукціонного дома «Корнерс» № 10 від 23.05.2009. С. 32.

2. Картина «Уголок сада». Русская антикварная галерея [Электронный ресурс]. Режим доступа: https://rus-gal.ru/works/kartinaugolok-sada/. Название с экрана. Дата обращения: 18.11.2020.

3. Ніколаєва Т. Повернення 3 небуття (архівні документи про українського художника I. Дряпаченка). Архіви України. 2013. № 4 (286). C. $143-155$.

4. Терещенко А. К. І. К. Дряпаченко. ЦДАМЛМ України, ф. 1144, оп. 1, спр. 14, арк. 215. 